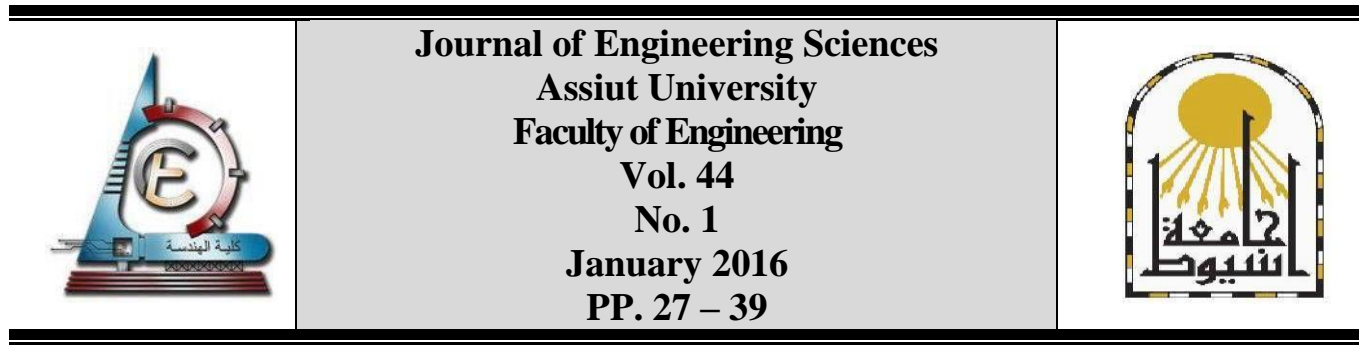

\title{
EXPERIMENTAL STUDY ON THE EFFECT OF PERMEABLE BLOCKAGE AT FRONT OF ONE PIER ON SCOUR DEPTH AT MULT-VENTS BRIDGE SUPPORTS
}

\author{
Nasr-Allah T. Hemdan ${ }^{1}$, Mohamed Y. Abdallah ${ }^{2}$, Abdel-Aal G. Mohamed ${ }^{3}$, \\ Basiouny $\mathrm{M}^{4}$, Amira Bahaa Abd-Elhasseb Abd-Elmaged ${ }^{\text {, * }}$ \\ ${ }^{1,4}$ Faculty of Engineering, Benha University, Egypt. \\ ${ }^{2,3}$ Faculty of Engineering ,Zagazig University, Egypt. \\ ${ }^{5}$ The Higher Institute of Engineering, El-Shorouk Academy, Egypt.
}

(Received 26 October 2015; Accepted 26 November 2015)

\begin{abstract}
Debris accumulation around bridge supports can constrict and redirect flow through the mutivents bridges resulting in significant bridge foundation scour. The experimental study of this paper, aims to investigate the effect of different porosities of partial blockage at front of bridge pier on local scour depth formed around bridge supports. The permeable blockage with different relative heights $\left(H / B_{p}=0.4,0.8\right.$ and 1.2) was fixed on and above the mobile bed. It was found that, for $15 \%$ porosity ratio of permeable blockage, the local scour depth at the left pier and right abutment was increased by $11.3 \%$ and $20 \%$ respectively compared to the no-blockage case. In addition the permeable blockage that placed at the water surface produces more local scour depth at multi-vents bridge supports compared to its location on the mobile bed.
\end{abstract}

Keywords: Local scour, Pier, Abutment, Permeable blockage, Hydraulic structures

\section{Introduction}

The piers and abutments are important elements of the bridge structure, can be susceptible to structural damage as a result of scour phenomenon. Debris flows composed of tree trunks leaf litter, logs and garbage bins. Debris accumulations can be considered as an obstruction, that resulting in higher velocities and vortex that create larger dimensions of scour holes around bridge foundation. It was recognized, that the increase in the expected scour depth owing to debris accumulation during the tail of high-flow events could be dangerous for the bridge, Franzetti et al [7]. Maatooq [13] described the scour, which is formed around bridge pier neighboring abutment. Abouzied et al. [1] studied the effect of the distance between piers, the diameter of the pier, shape of piers and bed sediment size on the local scour. Alabi [3] studied the time development of local scour at

* Corresponding author.

Email address: amera.fares19@yahoo.com 
bridge pier fitted with a collar. The effects of the angle of inclination of pier, and the pier shape and number on the local scour depth were studied by Mohammed, et al. [16]. Sanoussi and Habib [19] presented experimental results on the effect of the slope of the upstream pier face on the formation of local scour depth. Zha [24] carried out an experimental study for time-dependent scour depth under bridge-submerged flow. Khwairakpam [11], investigated the effect of varying inflow depths and densimetric Froude numbers on scour around a single pier. Ismael et al. [10] examined the effect of change the position of bridge pier to reduce the scour. Mohamed et al. [14] and [15] studied experimentally and numerically the scour at bridge abutment provided with different arrangements of collars. The local scour at single cylindrical pier (or groups) and the protection given by a rectangular slot through the pier, was studied by Farhan and Nalluri [6]. Mohamed et al. [17] studied experimentally the local scour depth around multivents bridge piers. Akib, et al. [2] examined the relationship between scour depth in complex pier groups and combined piles bridge and various parameters, including the variation of flow velocity, distance, and time. Douglas et al. [5] pointed out that large woody debris structures reduced velocities in the region adjacent to the bank toe and induced sediment deposition and retention. Lee, et al. [12] studied numerically the effect of bridge blockage resulting from floating containers and woody debris on local scour depth. Effects of debris on bridge pier scour were studied by Zevenbergen, et al. [23]. Effect of blockage and densimetric Froude number on circular bridge pier local scour was studied by Hodi [9]. Reynaud [18] developed guidelines for predicting the size and geometry of debris accumulations at bridge piers and methods for quantifying scour at bridge piers resulting from debris accumulations. The important factors affecting the blocking probability at bridge decks during flood events were evaluated by Schmocker and Hager [20]. The effect of blockage on cylindrical bridge pier local scour was studied by D'Alessandro [4]. The effects of blockage ratio and relative coarseness on clear water bridge pier scour were analyzed by Tejada [21]. Gamal et al. [8] predicted the maximum Scour around bridge piers due to Aquatic weed racks. Weeks [22] presented two equations to describe the entrance loss and energy loss coefficient for a culvert experiencing partial debris blockage while operations under outlet control conditions. In the present paper, the effect of different ratios of porosity of partial permeable blockage at front of bridge pier on local scour depth was investigated. In addition, the location of such these permeable obstructions either at mobile bed or water surface was studied also experimentally.

\section{Experimental work}

The experimental work was conducted in a re-circulating channel $0.4 \mathrm{~m}$ wide, $0.20 \mathrm{~m}$ deep and $5.70 \mathrm{~m}$ length. The discharge was measured using a pre-calibrated orifice meter. The scour depths formed in the mobile bed was measured by point gauge has 0.01 accuracy. Sand is uniform with $\mathrm{D}_{50}=0.75 \mathrm{~mm}$, at which the geometric stander deviation of the particle size distribution is less than 1.3 , in which geometric mean $=\left(\mathrm{D}_{85} / \mathrm{D}_{15}\right)>0.5$ $=1.27$. Three different ratios of porosity $(15 \%, 32 \%$ and $50 \%)$ were studied. The selected debris clusters were constructed with rectangular wire mesh baskets filled with gravels. The gravels ranged in diameter from $(0.4$ to $1.4 \mathrm{~cm})$ were placed into each debris cluster in a random orientation to achieve desired porosity of $50 \%, 32 \%$, and $15 \%$ of the gross volume. Clear water scour occurs for the velocities up to the threshold for the general bed movement. Two piers of the bridge model have $2.5 \mathrm{~cm}$ thickness and length (L) equals to $40 \mathrm{~cm}$ with circular shape at the nose and tail are used between the two abutments. The 
Nasr-Allah et al., Experimental study on the effect of permeable blockage at front of one pier on .....

width of each vents is $10 \mathrm{~cm}$. The values of Froude number are ranging from 0.33 to 0.54 . Typical test procedure consisted of (a) the mobile bed was leveled with the apron. (b) Selected discharge was allowed to pass. (c) The tail water depth was adjusted to a certain depth. (d) After 6 hours (at which $90 \%$ of the equilibrium scour depth was achieved) the discharge was stopped. (e) The sand was drained from water slowly to survey the scour hole using a mesh with dimension $1.0 \mathrm{~cm} \times 1.0 \mathrm{~cm}$ between piers and $5.0 \mathrm{~cm} \times 5.0 \mathrm{~cm}$ at upstream and downstream of them. (f) Steps from (a) to (e) were repeated for another tail water depth until satisfied. (g) The procedures were repeated for the desired range of Froude numbers. (h) a porous blockage with constant volume and height was used on the bed in front of the right pier and repeat steps from (a) to (f). The relative width of the blockage is 1.4. The different heights of partial permeable blockage with constant size at each previous porosity ratios are changed three times as shown in table (1).

\section{Dimensional analysis}

The dimensional analysis was used to define the dimensionless variables based on the selection of all variables governing the maximum scour depth upstream the bridge pier, see Fig. 1. The maximum relative scour depth was correlated to the other independent parameters using Buckingham theory as follow:

$$
d_{s} / y_{t}=f\left(F_{r}, H / B_{p}, h / B_{P} L / w, n\right)
$$

In which, $d_{s}$ is the maximum depth of scour, $y_{t}$ is the downstream tail water depth, $F_{r}$, is tail Froude number $\left(F_{r}=v /\left(g y_{t}\right)^{0.5}, g\right.$ is the gravitational acceleration, and $v$ is the mean flow velocity), $H$ is the height of blockage, $B_{p}$ is the Pier width, $h$ is the vertical distance from mobile bed to the base of blockage, $L$ is the Length of blockage, $w$ is the width of blockage and $n$ is the porosity ratio.

Table 1.

Arrangements of debris height and width at nose of right pier

\begin{tabular}{|c|c|c|c|c|c|}
\hline $\begin{array}{c}\text { Debris } \\
\text { Characteristic }\end{array}$ & Location & $\begin{array}{c}\text { Debris } \\
\text { Height }(\mathrm{cm})\end{array}$ & $\begin{array}{c}\text { Debris } \\
\text { Width }(\mathrm{cm})\end{array}$ & $\begin{array}{c}\text { Debris } \\
\text { Length }(\mathrm{cm})\end{array}$ & Width/Length \\
\hline \multirow{3}{*}{ porosity $15 \%$} & \multirow{9}{*}{ at bed } & 1 & 7 & 5 & \multirow{12}{*}{1.4} \\
\hline & & 2 & 5 & 3.5 & \\
\hline & & 3 & 4 & 2.9 & \\
\hline \multirow{3}{*}{ porosity $32 \%$} & & 1 & 7 & 5 & \\
\hline & & 2 & 5 & 3.5 & \\
\hline & & 3 & 4 & 2.9 & \\
\hline \multirow{6}{*}{ porosity $50 \%$} & & 1 & 7 & 5 & \\
\hline & & 2 & 5 & 3.5 & \\
\hline & & 3 & 4 & 2.9 & \\
\hline & \multirow{3}{*}{ at surface } & 1 & 5 & 7 & \\
\hline & & 2 & 3.5 & 5 & \\
\hline & & 3 & 2.9 & 4 & \\
\hline
\end{tabular}

\section{Analysis and discussions of results}

4.1 Effect of porosity of permeable obstruction (n) over mobile bed on local scour depth.

The effect of porosity of rectangular obstacle with constant size and relative height of permeable obstruction $\left(H / B_{p}\right)=0.4$ on local scour depth was investigated. Three different ratios of porosity $(n=15 \%, 32 \%$ and $50 \%)$ were inspected. Figures 2 through 5 show the relationship 
between $d_{s} / y_{t}$ and $F_{r}$ at different bridge supports, i.e., right pier $\left(\mathrm{P}_{\mathrm{r}}\right)$, right abutment $\left(\mathrm{A}_{\mathrm{r}}\right)$, left pier $\left(\mathrm{P}_{\mathrm{L}}\right)$, and left abutment $\left(\mathrm{A}_{\mathrm{L}}\right)$. The permeable obstruction was fixed at front of $\left(\mathrm{P}_{\mathrm{r}}\right)$ over the mobile bed, see Fig. 1. Figure 2 presents the local scour depth formed at $\left(\mathrm{P}_{\mathrm{r}}\right)$. It was found that, the permeable obstacle leads to pass flow through the porous media and uniform velocity distribution around $\left(\mathrm{P}_{\mathrm{r}}\right)$ will be obtained. So, the local scour depth was decreased for all porosity ratios (n) compared to the no-blockage case. From this figure also, it was noticed that, for the increasing of the porosity ratio from $15 \%$ to $32 \%$, the scour increases because of the flow passing through the pores increases vortices generated next to the pier thus increasing Scour. However the increase in the proportion of porosity up to $50 \%$ decreases scour comparing to porosity ratio $32 \%$. At which, more voids through the obstacle leads to calm flow and decrease velocity around the pier. Figures 3 and 4 show that the permeable obstruction at front of $\left(\mathrm{P}_{\mathrm{r}}\right)$ leads to increase the local scour depth at $\left(\mathrm{P}_{\mathrm{L}}\right)$ and $\left(\mathrm{A}_{\mathrm{r}}\right)$ compared to the noblockage case. The local scour depth upstream $\left(\mathrm{P}_{\mathrm{L}}\right)$ was increased by $11.3 \%, 4.5 \%$ and $3.5 \%$, for the porosity ratios $(15 \%, 32 \%$ and $50 \%)$ respectively. While, the local scour depth upstream the $\left(\mathrm{A}_{\mathrm{r}}\right)$ was increased by $20 \%, 12.3 \%$ and $4.4 \%$ for the same previous porosity ratios. For, the small porosity ratio, maximum values of local scour depth around $\left(\mathrm{P}_{\mathrm{L}}\right)$ and $\left(\mathrm{A}_{\mathrm{r}}\right)$ were generated compared to the base condition (no-blockage). Larger values of the porosity ratio share to increase the flow passing through the porous media at front of $\left(\mathrm{P}_{\mathrm{r}}\right)$ and decrease the reverse flow directed to $\left(\mathrm{P}_{\mathrm{L}}\right)$ and the $\left(\mathrm{A}_{\mathrm{r}}\right)$ (neighboring supports). The permeable obstacle has little effect on the local scour depth formed at $\left(\mathrm{A}_{\mathrm{L}}\right)$ which far from $\left(\mathrm{P}_{\mathrm{r}}\right)$, as shown in this Fig. 5. In which, the flow around left abutment has minor effect with the obstruction at $\left(\mathrm{P}_{\mathrm{r}}\right)$. The scour iso contour lines for the no-blockage and other impermeable blockage cases are shown in Fig. 6. It is clearly shown that the local scour depth generated at $\left(\mathrm{P}_{\mathrm{L}}\right)$ is high compared to the other bridge supports. In addition, as porosity of partial blockage decreases the scour hole dimension for the two adjacent bridges supports increases, i.e. $\left(\mathrm{A}_{\mathrm{r}}\right)$ and $\left(\mathrm{P}_{\mathrm{L}}\right)$.

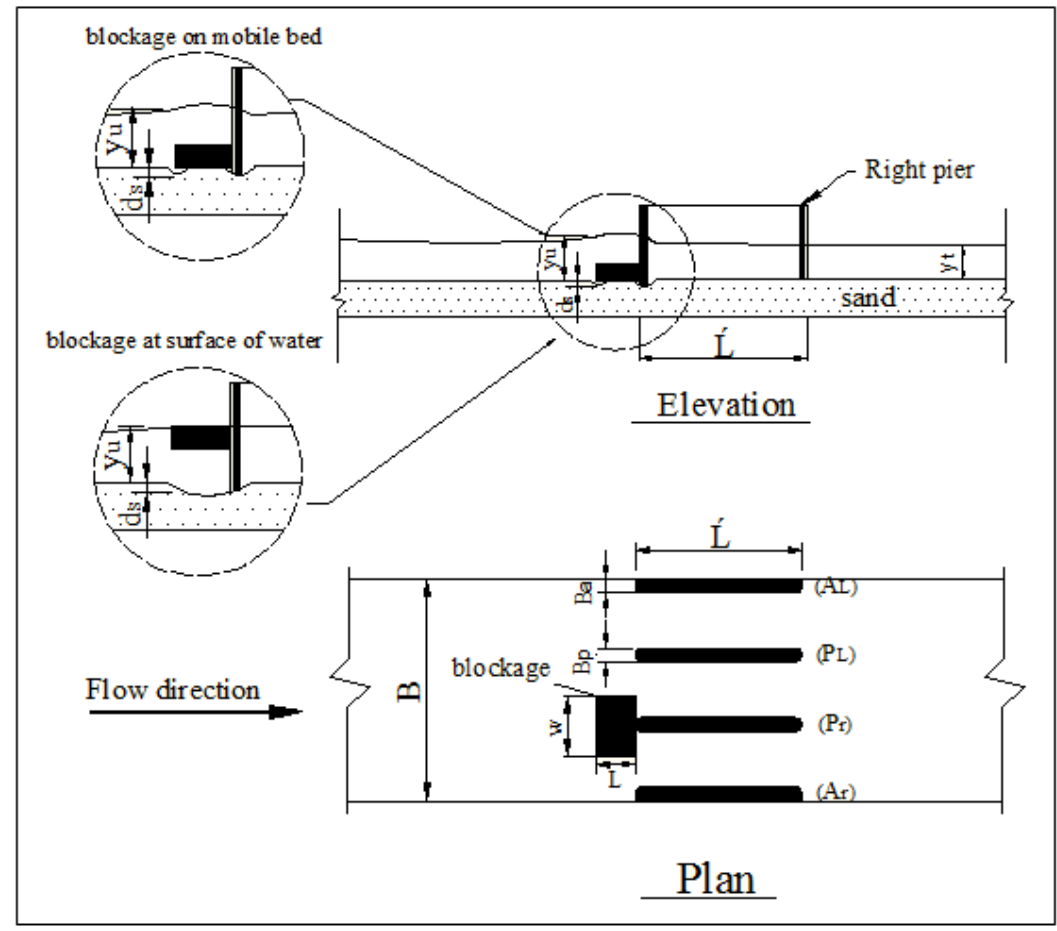

Fig. 1. Definition sketch for the experimental model 


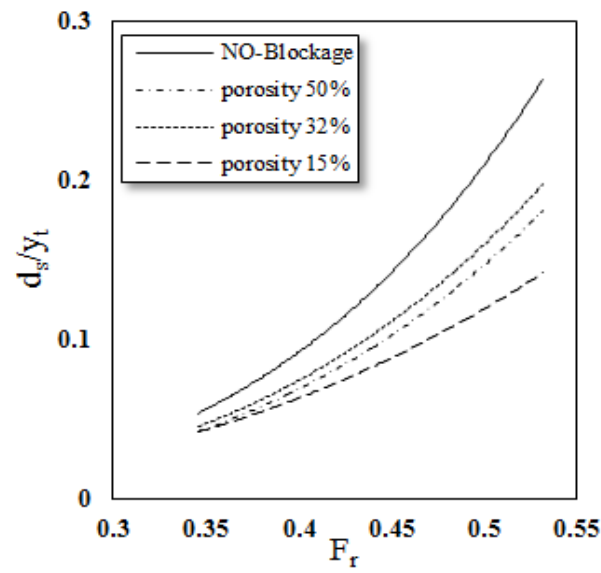

Fig. 2. The relationship between $d_{s} / y_{t}$ and $F_{r}$ for the right pier $\left(\mathrm{P}_{\mathrm{r}}\right)$ at $\mathrm{W} / \mathrm{L}=1.4, \mathrm{H} / \mathrm{B}_{\mathrm{P}}=0.4$ and different porosity ratios

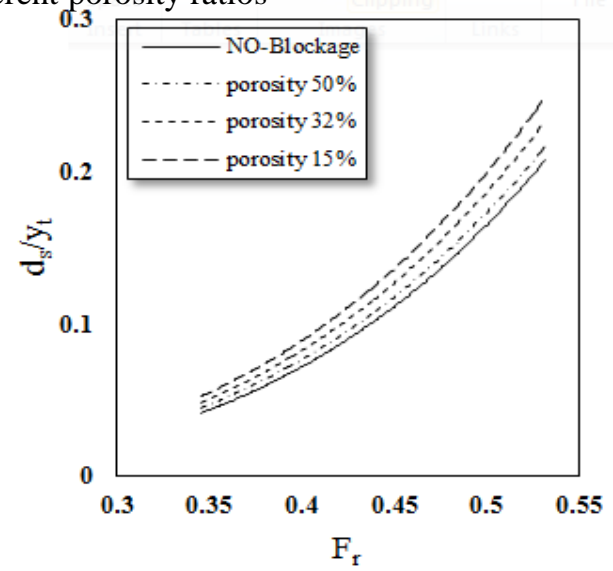

Fig. 4. The relationship between $d_{s} / y_{t}$ and $F_{r}$ for the right abutment $\left(\mathrm{A}_{\mathrm{r}}\right)$ at $\mathrm{W} / \mathrm{L}=1.4$, $\mathrm{H} / \mathrm{B}_{\mathrm{P}}=0.4$ and different porosity ratios

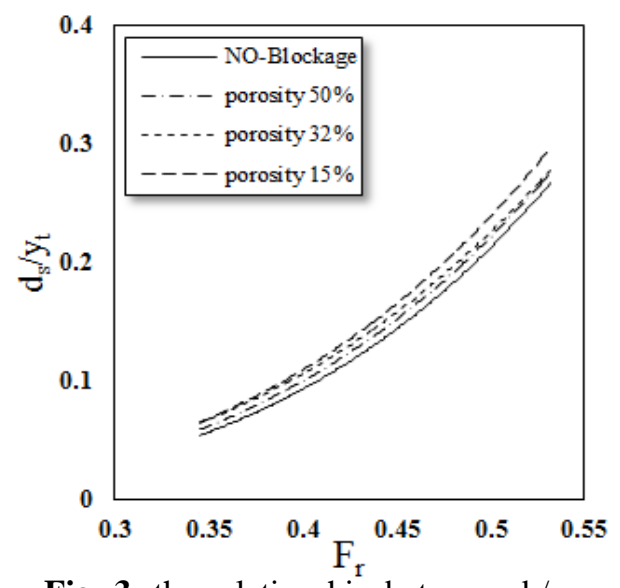

Fig. 3. the relationship between $d_{s} / y_{t}$ and $F_{r}$ for the left pier $\left(\mathrm{P}_{\mathrm{L}}\right)$ at $\mathrm{W} / \mathrm{L}=1.4, \mathrm{H} / \mathrm{B}_{\mathrm{P}}=0.4$ and different porosity ratios

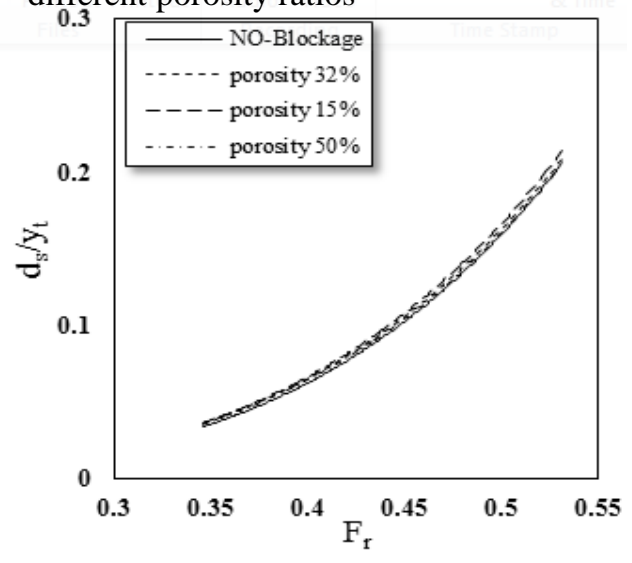

Fig. 5. The relationship between $d_{s} / y_{t}$ and $F_{r}$ for the left abutment $\left(\mathrm{A}_{\mathrm{L}}\right)$ at $\mathrm{W} / \mathrm{L}=1.4, \mathrm{H} / \mathrm{B}_{\mathrm{P}}=0.4$ and different porosity ratios

\subsection{Effect of the location of permeable obstruction with different thickness on} local scour depth.

The effect of debris location was investigated using permeable partial blockage with 50\% porosity, 1.4 relative width $(W / L)$ and different relative heights $\left(H / B_{P}\right)$. The permeable blockage cluster were fixed as follow; i) over the mobile bed, and ii) the top surface of porous obstacle coincides with the water surface and has different ratios of $H / B_{P}$. Figure 7 presents the relationship between Froude number and relative scour depth with porosity $(n)$ equals $50 \%, W / L$ equals 1.4 and deferent ratios of $\left(H / B_{P}\right)$. It was found that, the local scour depth increases as the relative height of obstruction and Froude number increase. In addition, the local scour depth formed for case of permeable obstruction at the water surface had greater values compared to the case if permeable blockage on the bed. Moreover, the presence of permeable blockage at water surface increases the local scour depth at $\left(\mathrm{P}_{\mathrm{r}}\right)$ by 4.97 times compared to the situation of its presence at the mobile bed. The permeable partial blockage with relative porosity ratio $(\mathrm{n}=50 \%)$ at water surface increases local scour depth at 
$\left(\mathrm{A}_{\mathrm{r}}\right)$ by $64.3 \%, 58.96 \%$ and $52 \%$, for different relative heights of blockage $\left(H / B_{P}=1.2,0.8\right.$, and 0.4 ) respectively, compared to the no-blockage case.

The local scour depth, which formed at the upstream of $\left(\mathrm{P}_{\mathrm{r}}\right)$ increases by $(87 \%, 73 \%$ and $58 \%$ ) for the studied ratios of $H / B_{P}$ respectively, in case of the obstacle at water surface, conversely the existence of such obstacle on the bed decreases the local scour depth upstream $\left(\mathrm{P}_{\mathrm{r}}\right)$ by $62 \%, 57 \%$ and $30.5 \%$ for the studied ratios of $H / B_{P}$ respectively, compared to the no-blockage case. The scour iso lines for the obstacle at water surface with porosity $(n=50 \%)$ and different relative height were shown in Fig. (8). It was noticeable from this figure that, greater scour occurs at $\left(\mathrm{P}_{\mathrm{r}}\right)$, which holding the obstacle. In addition the local scour depth at the bridge supports $\left(\mathrm{P}_{\mathrm{L}}, \mathrm{A}_{\mathrm{r}}\right.$, and $\left.\mathrm{A}_{\mathrm{L}}\right)$ increases as the thickness of the debris blockage increases.

\section{Statistical analysis}

The multiple linear regressions are applied to predict statistical equations. The proposed equations correlate the relative scour depth $\mathrm{d}_{\mathrm{s}} / \mathrm{y}_{\mathrm{t}}$ with other independent parameters at multivents bride supports, i.e. $\left(\mathrm{P}_{\mathrm{L}}, \mathrm{P}_{\mathrm{r}}, \mathrm{A}_{\mathrm{r}}\right.$, and $\left.\mathrm{A}_{\mathrm{L}}\right)$. These equations have the follow forms;

$$
\begin{aligned}
& \left(\frac{d_{s}}{y_{t}}\right)_{P_{L}}=-0.42-0.04(n)+0.05 \mathrm{H} / \mathrm{H}_{p}+0.05 \mathrm{~h} / \mathrm{H}_{p}+1.3 F_{r} \\
& \left(\frac{d_{s}}{y_{t}}\right)_{P_{r}}=-0.35-0.07(n)-0.03 \mathrm{H} / \mathrm{H}_{p}+0.013 \mathrm{~h} / \mathrm{H}_{p}+F_{r} \\
& \left(\frac{d_{s}}{y_{t}}\right)_{A_{r}}=-0.41-0.020 \mathrm{n}+0.049 \mathrm{H} / \mathrm{H}_{p}+0.028 \mathrm{~h} / \mathrm{H}_{p}+1.24 F_{r} \\
& \left(\frac{d_{s}}{y_{t}}\right)_{A_{L}}=-0.31-0.006(n)+0.01 \mathrm{H} / \mathrm{H}_{p}+0.02 \mathrm{~h} / \mathrm{H}_{p}+0.95 F_{r}
\end{aligned}
$$

Figures 9 through 12 present the predicted values for $\mathrm{P}_{\mathrm{L}}, \mathrm{P}_{\mathrm{r}}, \mathrm{A}_{\mathrm{r}}$, and $\mathrm{A}_{\mathrm{L}}$ versus both of measured data and residuals, respectively. The coefficient of determination and standard error are (92\%, and 0.03), (54\%, and 0.07), (92\%, and 0.02), and (94\%, and 0.01) for Eqs. $2,3,4$, and 5 respectively. These results indicate that, the predicted models for relative local scour depth at bridge supports express well the measured data. 
Nasr-Allah et al., Experimental study on the effect of permeable blockage at front of one pier on .....

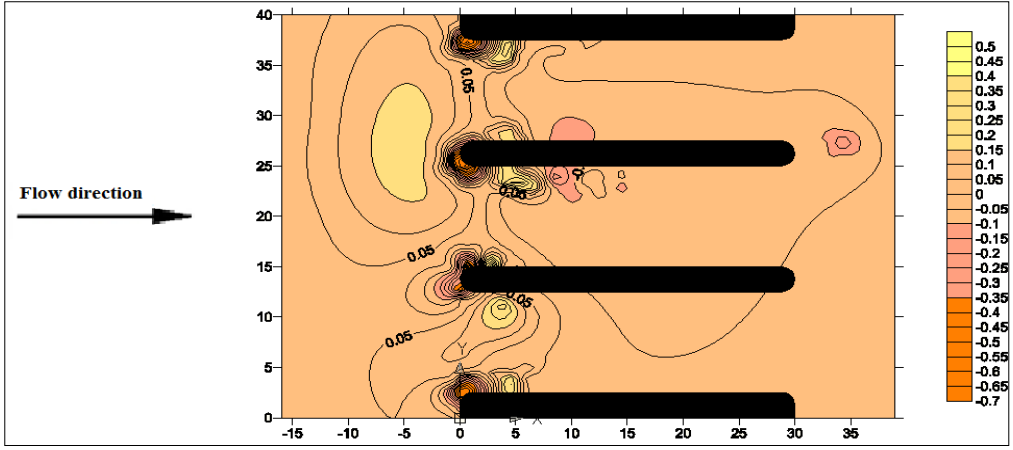

(a)

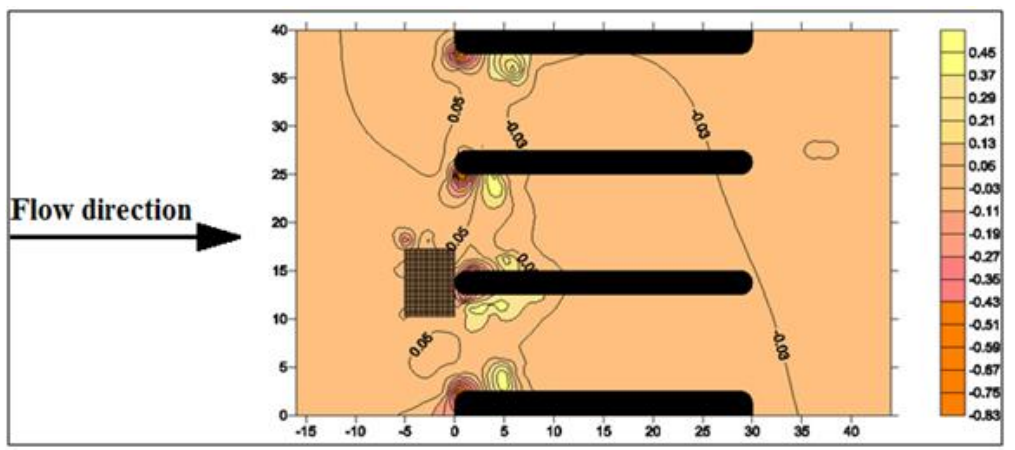

(b)

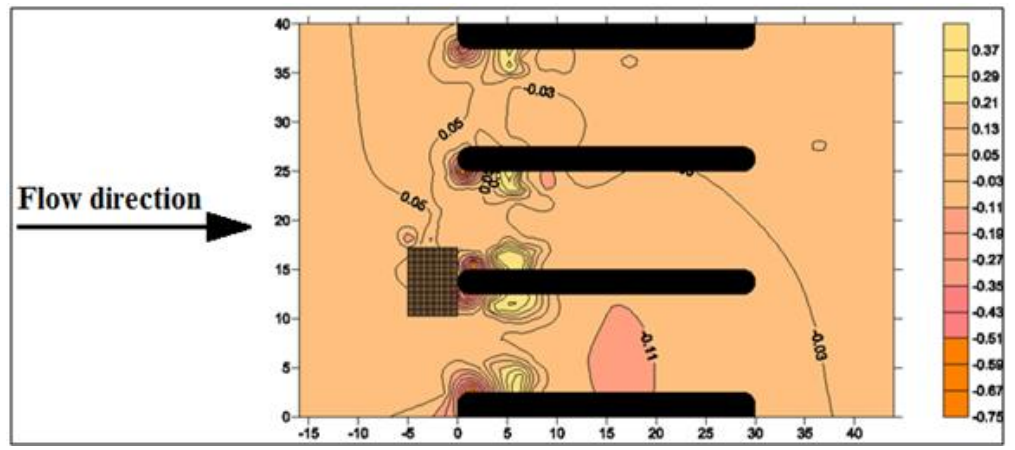

(c)

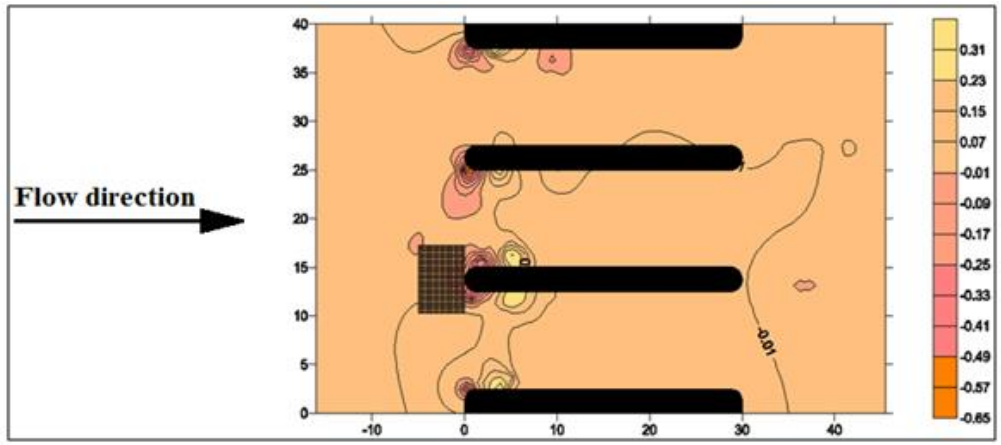

(d)

Fig. 6. Scour iso lines for (a) no-blockage (b) $15 \%$ porosity, (c) $32 \%$ porosity and (d) $50 \%$ porosity with $H / B_{P}=0.4$ and $W / L=1.4$ at $F_{r}=0.53$. 

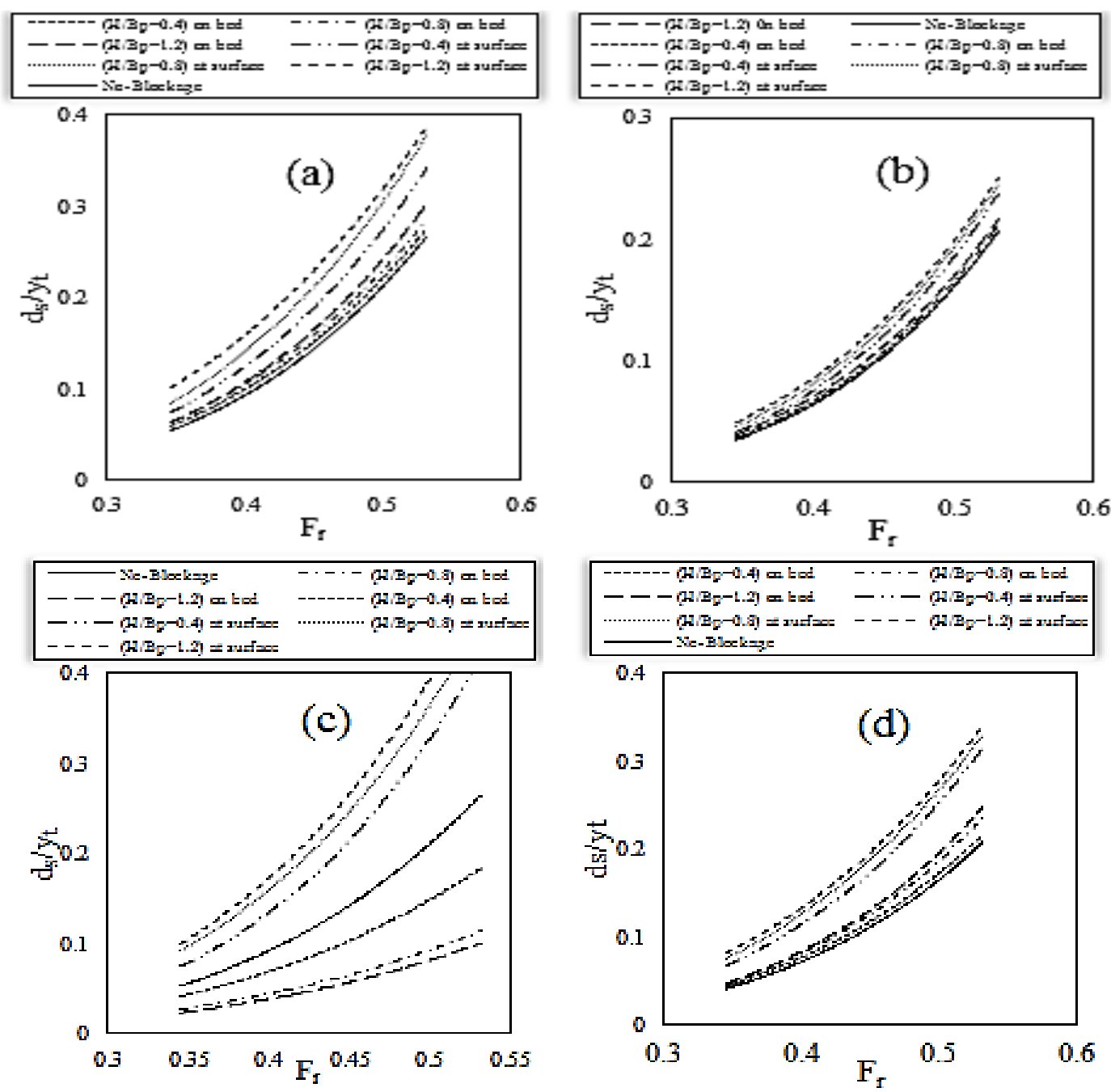

Fig. 7. The relationship between $d_{s} / y_{t}$ and $F_{r}$, for (a) left pier $\left(\mathrm{P}_{\mathrm{L}}\right)$, (b) left abutment $\left(\mathrm{A}_{\mathrm{L}}\right),(\mathrm{c})$ right pier $\left(\mathrm{P}_{\mathrm{r}}\right)$, and $(\mathrm{d})$ right abutment $\left(\mathrm{A}_{\mathrm{r}}\right)$ at porosity ratio $\mathrm{n}=50 \%, \mathrm{~W} / \mathrm{L}=1.4$ and different ratios of $H / B_{P}$

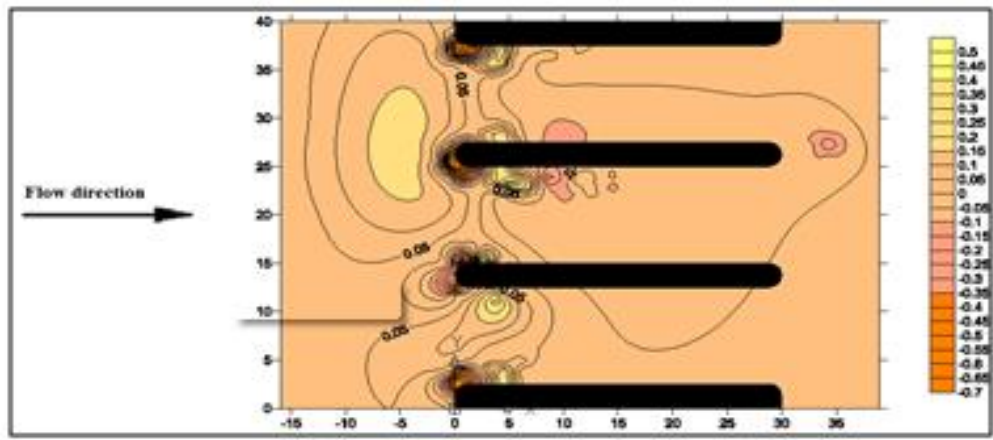

(a) 
Nasr-Allah et al., Experimental study on the effect of permeable blockage at front of one pier on .....

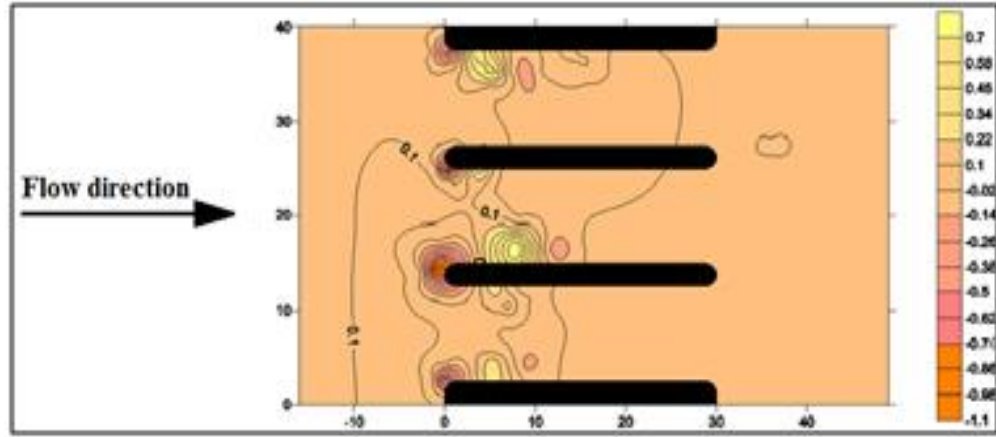

(b)

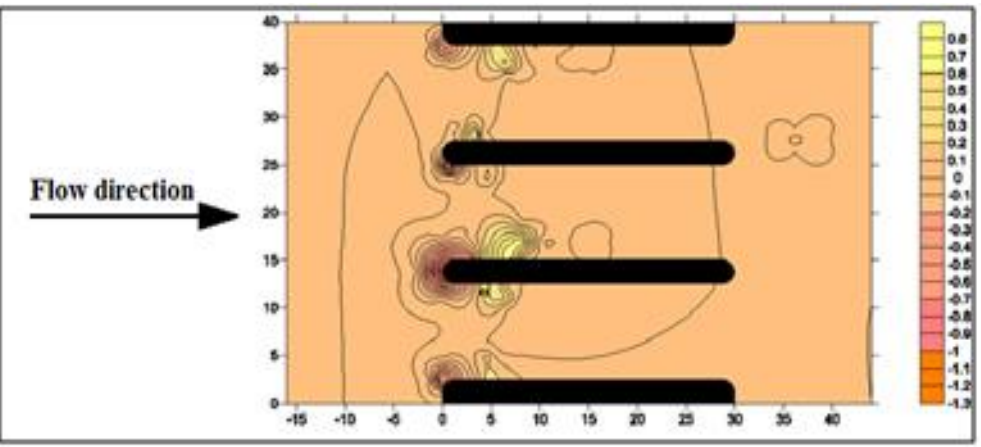

(c)

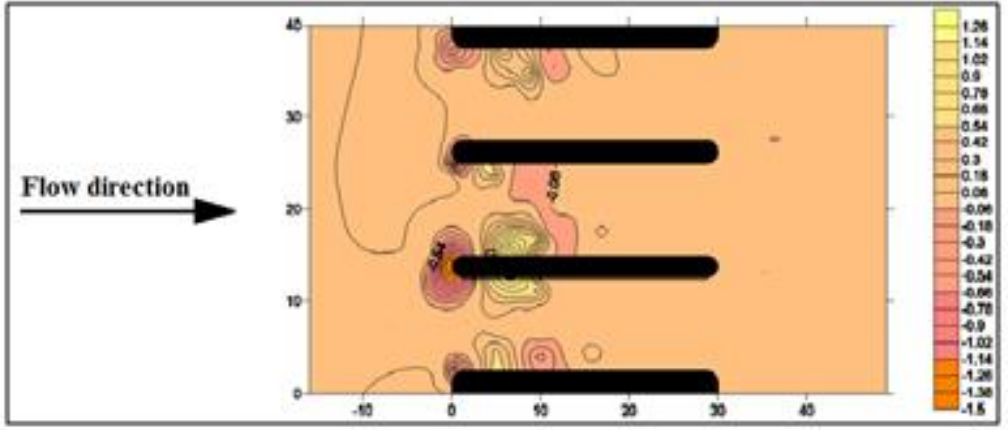

(d)

Fig. 8. Scour iso lines for permeable obstruction at water surface for (a) no-blockage case, (b) $H / B_{p}=0.4$, (c) $H / B_{P}=0.8$ and (d) $H / B_{P}=1.2$ with $n=50 \%, \mathrm{~W} / \mathrm{L}=1.4$ and $F_{r}=0.53$
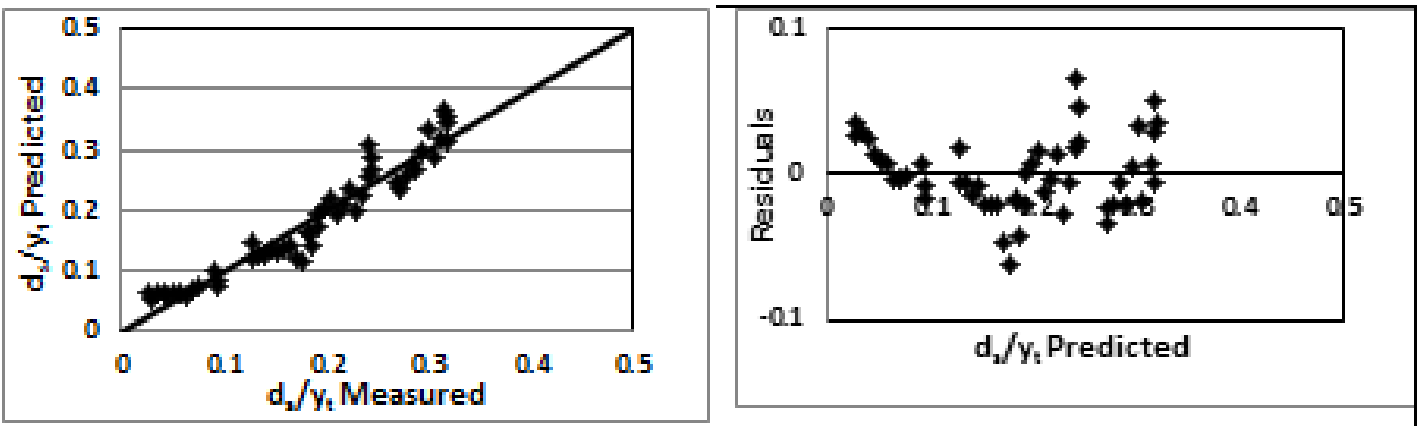

Fig. 9. Eq. 2 presents the predicted $\left(d_{s} / y_{t}\right)$ data versus measured data $(d s / y t)$ and residuals, for $P_{L}$. 

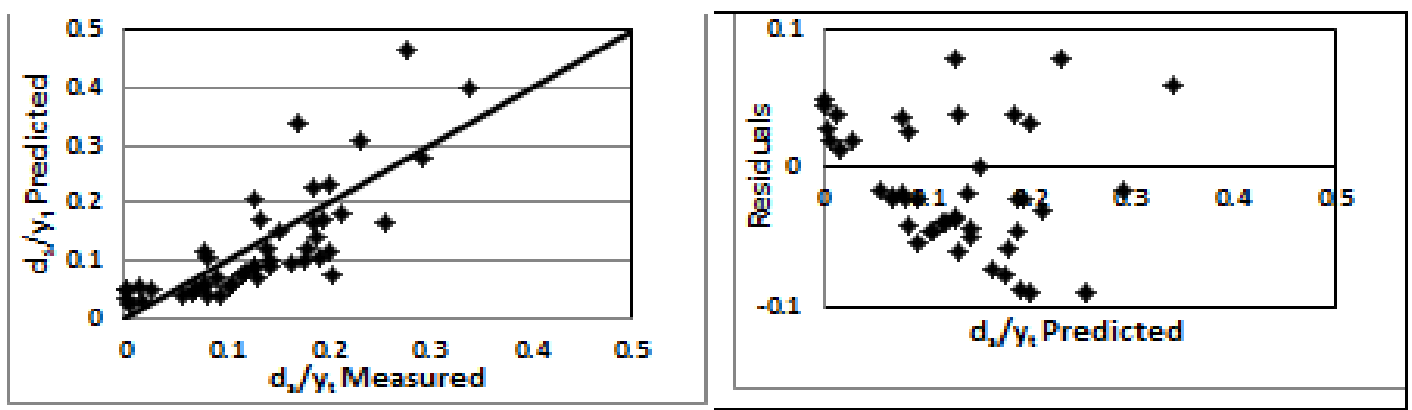

Fig. 10. Eq.3 presents the predicted $\left(d_{s} / y_{t}\right)$ data versus measured data $\left(d_{s} / y_{t}\right)$ and residuals, for $P_{r}$.
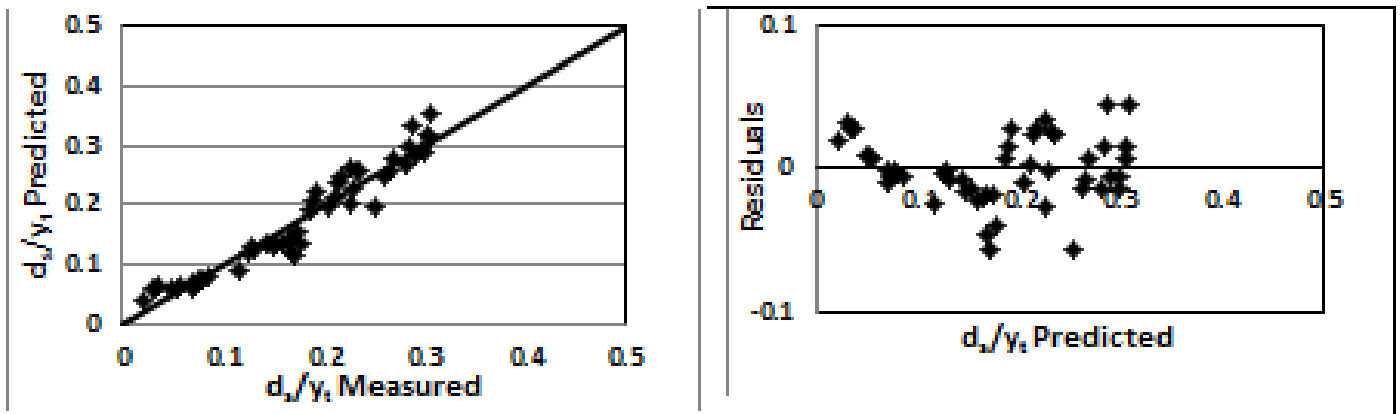

Fig. 11. Eq. 4 presents the predicted $\left(d_{s} / y_{t}\right)$ data versus measured data $\left(d_{s} / y_{t}\right)$ and residuals, for $A_{r}$.
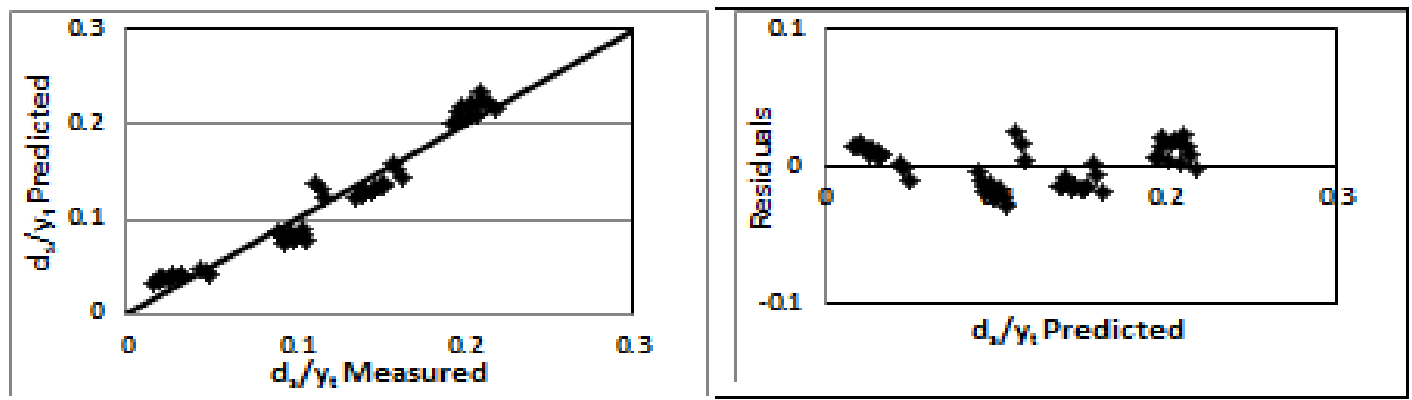

Fig. 12. Eq.5 presents the predicted $\left(d_{s} / y_{t}\right)$ data versus measured data $\left(d_{s} / y_{t}\right)$ and residuals, for $A_{L}$.

\section{Conclusions}

The following conclusions could be summarized as follow;

1) The relative local scour depth increases as the porosity ratio of the obstruction decreases.

2) The permeable obstruction rested on the bed in front of pier resulted in greater depths of scour at adjacent pier and abutment than no-blockage condition.

3) The $15 \%$ porosity ratio of obstruction over the mobile bed increases the local scour depth at adjacent pier and abutment by $11.3 \%$, and $20 \%$ respectively, compared to no-blockage condition.

4) The pier infected by permeable obstruction over mobile bed has lower values of local scour depth compared to no-blockage condition while this obstruction adversely affect the rest of the other bridge supports 
5) The permeable partial blockage at water surface with $n=50 \%$, increases local scour depth at the infected pier $\left(\mathrm{A}_{\mathrm{r}}\right)$ by $64.3 \%, 58.96 \%$ and $52 \%$, for $H / B_{P}=1.2$, 0.8 , and 0.4 respectively, compared to the no-blockage case.

6) The porosity blockage with relative width $=1.4$ and relative height $=1.2$ and its top surface coincide with water surface causes greater scour at the right piers by 4.97 times of the scour created by the obstacle rested on the bed.

7) The statistical equations, predicting local scour depth at multi-vents bridge supports, agree well with the measured data.

\section{Nomenclature}

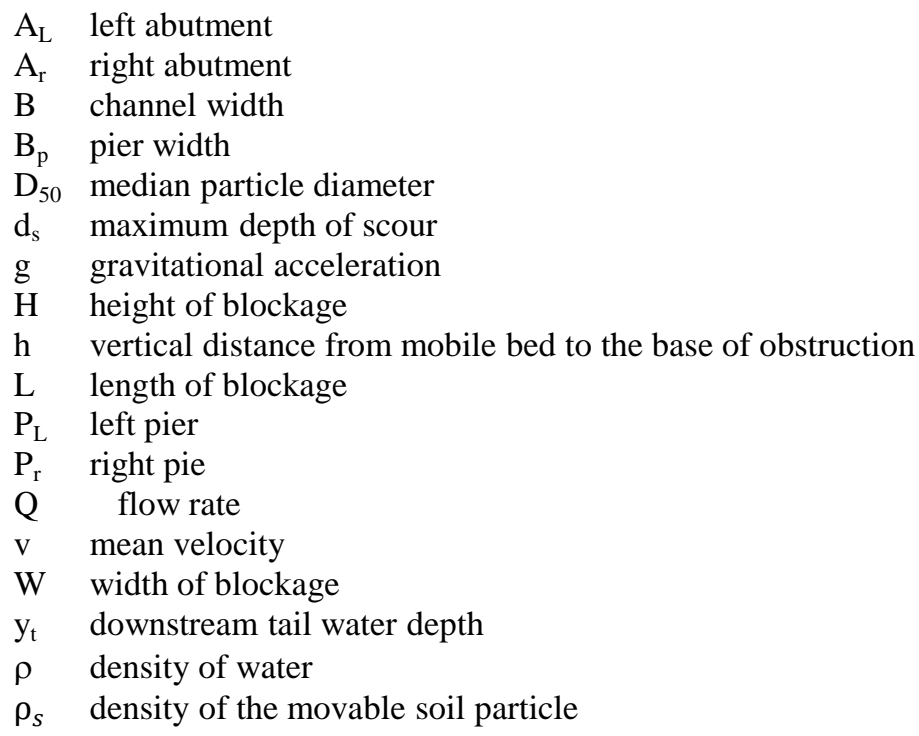

\section{REFERENCES}

[1] Abouzeid, G.A., Mohamed, H.I., Ali, S.M., 2006. 3-D Numerical simulation of flow and clear water scour by interaction between bridge piers. $10^{\text {th }}$ Water Technology Conference, IWTC10, Alexandria, Egypt pp. 899 - 915.

[2] Akib, S., Jahangirzadeh, A., Basser, H., 2014. Local scour around complex pier groups and combined piles at semi-integral bridge. Jornal of. Hydromech. Vol. 2, pp. 108-116.

[3] Alabi, P.D., 2006. Time development of local scour at a bridge pier fitted with a collar. A thesis MSC. Pp. (221).

[4] D'Alessandro, C., 2013. Effect of blockage on cylindrical bridge pier local scour. Electronic Theses and Dissertations. Paper 4966.

[5] Douglas Shields Jr., M. ASCE, Morin N., Cooper C.M., 2004. Large woody debris structures for sand-bed channels". Journal of Hydraulic Engineering, Vol. 130, No. 3, pp. 208-217.

[6] Farhan, A.M.E., Nalluri, C., 2014. Local scour around bridge piers- a study of its effects around cylindrical pier groups'. Universidad De Los Andes, pp. 46-52.

[7] Franzetti, S., Radice, A., Rabitti, M., Rossi, G., 2011. Hydraulic design and preliminary performance evaluation of countermeasure against debris accumulation and resulting local pier scour on River Po in Italy" Journal of Hydraulic Engineering, Vol. 137, No. 5, pp. 615-620.

[8] Gamal, T., Hosny, M., Al_Samman, T., Aboul_Atta, N., 2013. Prediction of maximum scour around bridge piers due to aquatic weed racks" International Journal of Engineering Research \& Technology (IJERT). Vol. 2 Issue 6. Pp. (9). 
[9] Hodi, S.B., 2009. Effect of blockage and densimetric Froude number on circular bridge pier local scour". MSc Thesis, University of Windsor, pp. (97).

[10] Ismael, A., Gunal, M., Hussein, H., 2013. Influence of bridge pier position according to flow direction on scour reduction. Proc. of the Intl. Conf. on Advances in Civil, Structural and Environmental Engineering, ACSEE, Copyright (C) Institute of Research Engineers and Doctors. All rights reserved ISBN: 978-981-07-7965-8, pp. 12-16.

[11] Khwairakpam, P., Ray, S.S., Das, S., Das R., Mazumdar, A., 2012. Scour hole characteristics around a vertical pier under clearwater scour conditions. ARPN Journal of Engineering and Applied Sciences (02006-2012 Asian Research Publishing Network (ARPN). All rights reserved. Vol.7, No. 6, pp. 649-654.

[12]Lee, K.T., Ho. Y., Chyan, Y., 2006. Bridge blockage and overbank flow simulations using HEC-RAS in the Keelung River during the 2001 Nari Typhoon. Journal of Hydraulic Engineering, Vol. 132, No. 3, pp 319-323.

[13] Maatooq, J.S., 2005. Interference of scouring action between pier and abutment. Journal of Eng.\&Tech.Vol. 26, No. 52008, pp. (7)

[14] Mohamed, Y.A, Abdel-Aal, G.M., Nasr-Allah, T.H., Awad, A.S., 2013. Experimental and theoretical investigations of scour at bridge abutment" Journal of King Saud University, Engineering Sciences.

[15] Mohamed, Y.A, Abdel-Aal, G.M., Nasr-Allah, T.H., Awad, A.S., 2014 Investigating the effect of curved shape of bridge abutment provided with collar on local scour, experimentally and numerically. Ain Shams Engineering Journal.

[16] Mohammed, T.A., Noor, M.J., Ghazali, A., Yusuf, B., Saed, K., 2007. Physical modeling of local scouring around bridge piers in erodible bed. J. King Saud Univ., Vol. 19, Eng. Sci. (2), pp. 195-207, Riyadh.

[17] Mohammed, Y.,A., Saleh, Y.K., Ali, A.M., 2015. Experimental investigation of local scour around multi-vents bridge piers. Alexandria Engineering Journal (54), 197-203

[18] Reynaud, D.A., 2010. Effects of debris on bridge pier scour. National Academy of Sciences. Pp. (177).

[19] Sanoussi, A.A., Habib, E.A., 2008. Local scour at rounded and sloped face piers with skew angles. ICCBT 2008 - D - (41) - pp. 439-462.

[20] Schmocker, L. Hager, W. H., 2010. Probability of drift blockage at bridge decks". Journal of Hydraulic Engineering ,Vol. 137, No. 4. Pp. 470-479.

[21] Tejada, S., 2014. Effects of blockage and relative coarseness on clear water bridge pier scour. Electronic Theses and Dissertations. Paper 5055. Pp. (155).

[22] Weeks, W., 2014. Blockage of hydraulic structures. Australia water engineering. Project 11.pp 18-19.

[23]Zevenbergen, L.W., Lagasse, P.F., Clopper, P.E., 2007. Effects of debris on bridge pier scour. World Environmental and Water Resources Congress, pp. (10).

[24]Zha, Y., 2010. Time-dependent scour depth under bridge-submerged flow. Civil Engineering Theses, Dissertations, and Student Research. Paper 4. Pp. (85). 
Nasr-Allah et al., Experimental study on the effect of permeable blockage at front of one pier on .....

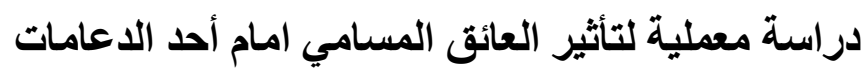

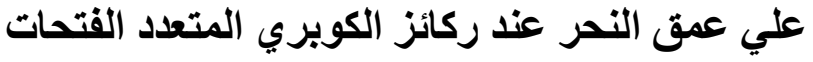

المستخلص العربي

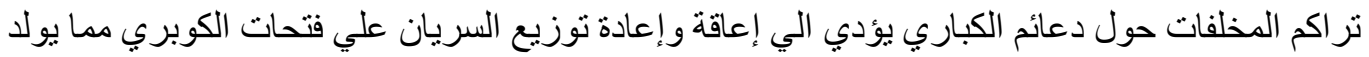

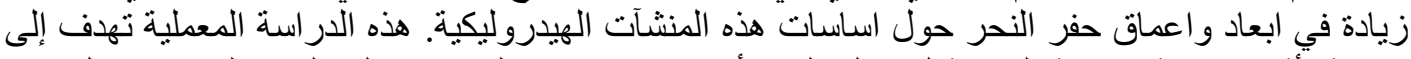

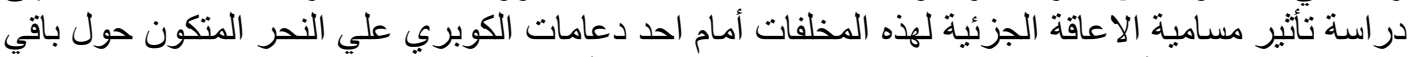

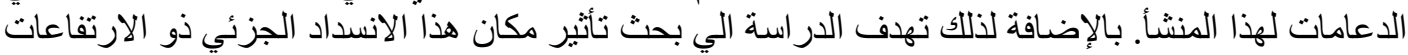

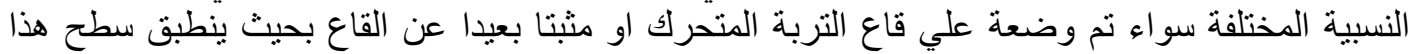

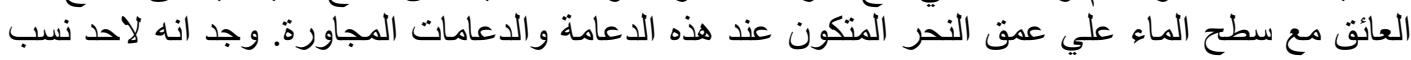

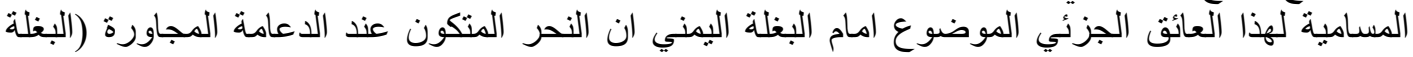

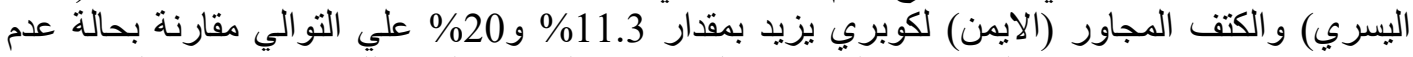

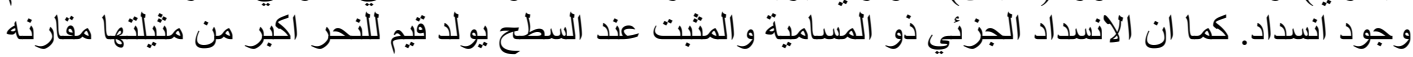

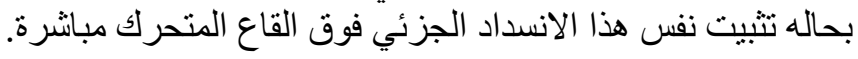

